\title{
Twins Separated at Birth: Across a Country and Around the World/Twin Research: Memorial Tribute to Isaac Blickstein, MD; Infanticide and Sacrifice of Archaic-Aged Twins and Triplets; Prehistoric Twin Burials; Highlights from a Conference on Three Identical Strangers/Media Reports: An Atypical Twin Father; An Actor's Twin Brother; Twin Link to Tulsa, Oklahoma Massacre; Superfetated Twins; Twin Comedians and Script Writers; Indian Twins' Loss to COVID-19
}

\author{
Nancy L. Segal \\ Department of Psychology, California State University, Fullerton, CA, USA
}

\begin{abstract}
Every reared-apart monozygotic (MZ) twin pair offers a fresh perspective on human developmental questions. This is true regardless of whether the co-twins were raised in the same country or across the globe. The members of two pairs of separated MZ female twins have recently come to attention. In one case the twins were raised by different families in Argentina; in the other case the twins were raised by different families in Sweden and Vietnam. The perceptions and perspectives of these twins are insightful. The twin research section that follows begins with a tribute to our late esteemed colleague, Dr Isaac Blickstein (1953-2020). Research concerning the infanticide and sacrifice of Archaic-aged twins and triplets and prehistoric twin burials is reviewed next. Highlights from a conference focused on the 2018 film Three Identical Strangers are also included in this portion. The final section of this article includes media reports of an atypical twin father, an actor's twin brother, a twin link to the 1921 Tulsa, Oklahoma massacre, the birth of superfetated twins, twin comedians and script writers and Indian twins' tragic loss to COVID-19.
\end{abstract}

This article is dedicated to the memory of Michele Mordkoff, one of the twins separated from her sister by New York's Louise Wise Agency in 1964. Michele passed away from an untimely death at the age of 57 - she and her twin sister Allison had known each other for less than 3 years. Michele was a marvelous source for my forthcoming book, Deliberately Divided intelligent, caring and compassionate. She will be missed.

\section{Twins Separated at Birth: Across a Country and Around the World}

Reared-apart twins can be separated by cities, states, countries or continents, but they are always a rich source of information surrounding genetic and environmental factors that shape behavior. I recently learned of two new cases of adopted-apart

\footnotetext{
Author for correspondence: Nancy Segal, Email: nsegal@fullerton.edu

Cite this article: Segal NL. (2021) Twins Separated at Birth: Across a Country and Around the World/Twin Research: Memorial Tribute to Isaac Blickstein, MD; Infanticide and Sacrifice of Archaic-Aged Twins and Triplets; Prehistoric Twin Burials; Highlights from a Conference on Three Identical Strangers/Media Reports: An Atypical Twin Father; An Actor's Twin Brother; Twin Link to Tulsa, Oklahoma Massacre; Superfetated Twins; Twin Comedians and Script Writers; Indian Twins' Loss to COVID-19. Twin Research and Human Genetics 24: 244-250, https://doi.org/10.1017/ thg. 2021.30
}

monozygotic (MZ) female twins who are eager to share their life histories. The twins in one set - Dolores and Mirta - were raised in Argentina, in the cities of Córdoba and Moreno, respectively. These cities are over 1000 miles apart. I learned about this pair from 'DuoLingo', a radio program that presents interesting stories in two languages for people trying to learn a foreign language (DuoLingo, 2021). The twins in the other set - Alice and Linh - were raised in Sweden and Vietnam, respectively. I learned about them when Alice sent me an email to inquire about research participation. She had been referred to me by the Karolinska Institute in Stockholm.

I was able to send follow-up questions to three of the four twins. Dr Laura A. Pérgola, founder of the Multifamilias Foundation in Argentina, assisted me with posing questions to Mirta and Dolores. I sent questions directly to Alice, who is fluent in English.

The twins in both sets have known each other for a number of years. Mirta and Dolores first met 10 or 11 years ago, at age 50, in the city of Moreno where Mirta lives. The year before they met, Dolores had first learned from a cousin that she had been adopted, although she had suspected this for some time. As a child, she had observed that her parents were much older than the mothers and 
fathers of her friends - she also 'sensed' that she was not their biological child. Dolores' journey toward learning of her twinship and finding her sister reads like a thriller.

Alice, who is now 30 years of age, was adopted when she was 10 months old. She learned that she had a twin when she was 16, meeting Linh for the first time when they turned 20. The vast distance between their home countries of Sweden and Vietnam (5370 airline miles) explains why these twins have met in person on only two occasions; however, they stay in contact through Facebook, Instagram and group chats with the help of bilingual friends. Alice's discovery of her twin sister is an extraordinary story that I will describe later. I will begin with Dolores and Mirta.

\section{Dolores and Mirta}

Dolores was adopted as a baby after her parents brought her home from a house in the countryside near Córdoba. Her parents listened to her childhood questions about being adopted, but they denied it consistently. Then at age 24, having earned a college degree in Spanish literature and history, Dolores accepted a teaching job in Neuquén, a city located 1000 miles from Córdoba. There she met her husband, continued to work and began raising two children. She gave little thought to her biological background and family. Fifteen years later, in 2007, Dolores encountered a cousin who confirmed her suspicions about having been adopted - apparently it was an 'open' family secret. At this point, Dolores vowed to discover her biological origins. She contacted an uncle who had been a signatory on her birth certificate. He reconfirmed the fact of her adoption, but he also revealed that she had a twin sister. Dolores was determined to find her. In May 2008, she traveled to Córdoba in search of birth records, but uncovered no clues.

Twins in a several separated pairs have met due to mistaken identity - someone who knows one twin sees an identical other and assumes that this other is the person whom they know. That happened here. In May 2010, Dolores' daughter's friend phoned to say that she had seen Dolores interviewed on Crónica TV regarding a criminal investigation. Dolores had been near the courthouse that day, but she had not been interviewed. Dolores wondered if this woman could be her twin sister. She turned on the television thinking that the interview might be rebroadcast. It was not, but she did watch an interview about a different case with a woman from the city of Moreno who looked exactly like her. With the help of a priest from Moreno, Dolores found her sister - her name was Mirta. A. neighbor who was familiar with the story met with Mirta first to prepare her for a reunion with her twin sister.

Dolores and Mirta met in Moreno on June 17, 2010, having talked on the telephone a great deal over the two weeks prior to Dolores meeting her twin. As Mirta described it, when they met the twins alternated between hugging each other and standing back to stare. They looked exactly alike. According to Dolores, 'this woman had brown eyes identical to mine. The shape of her face was the same, even her nose! The first things that caught my attention were her hands. She moved them just like me. (Both twins are right-handed.) When I heard her speak, I couldn't believe it! It was the same tone of voice as mine. She was not only my sister - she was my twin sister!' It turned out that Mirta had also suspected she was adopted, a fact that her parents had also denied. Interestingly, Mirta conceived twins, but when asked about her medical history by her doctor, she indicated that there were no twins in her family. It was not until she was 40 that her mother finally told her she had been adopted and that she had a twin sister. At that time Mirta

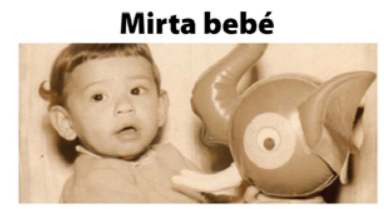

Mirta 5 años

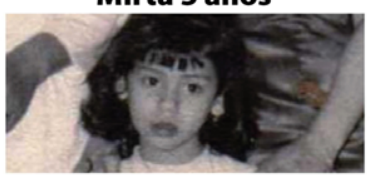

Mirta 15 años

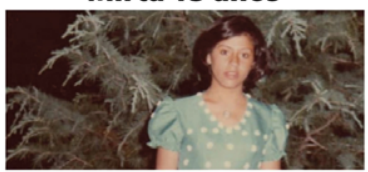

Mirta 30 años

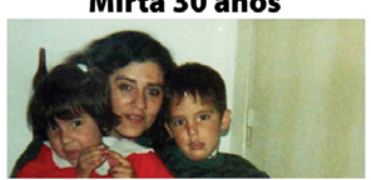

Cosa Linda me trajo la vida, y no necesito Mas!

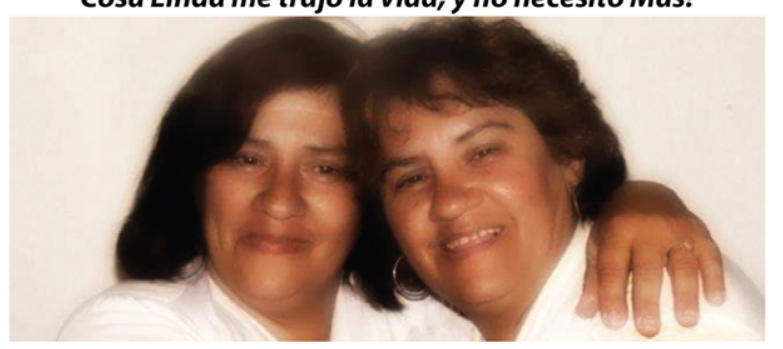

Fig. 1. Reared-apart monozygotic twins, Mirta (L) and Dolores (Lola) (R) from Argentina, at different ages. Años means years. Adult photograph: Mirta (L) and Dolores (R). The caption reads: Life brought me such a pretty thing and I could not ask for more. Courtesy of the twins and Dr Laura Pérgola.

lacked the strength to search for her twin. The twins are shown in Figure 1.

I asked the twins about their childhood and adult similarities and differences. Their most striking similarity is that both played solitary Scrabble as a child and never cheated - neither twin tolerates dishonesty. Both twins are also very orderly, passionate about chocolate and known for doing their jobs well. They share political views, health histories, preferences for specific televised series and understanding of their parents' decisions to hide their adoption and twinship. The twins' differences include attitudes toward dogs, number of friends, interest in cooking and level of activity.

Most importantly, Mirta and Dolores are delighted to have met one another, acquiring in-laws, nieces and nephews in the process. They still get excited when they think about having discovered one another and reuniting. According to Dolores, 'The moment of meeting... wonderful, indescribable. It was the same feeling I had when my son was born, and I saw his little face. It was being born again and [holding] each other in an endless embrace - as if we had known each other forever'.

\section{Alice and Linh}

Alice and Linh were born in Hanoi in July 1991. Alice, who joined her Swedish family when she was 10 months old, always knew she 


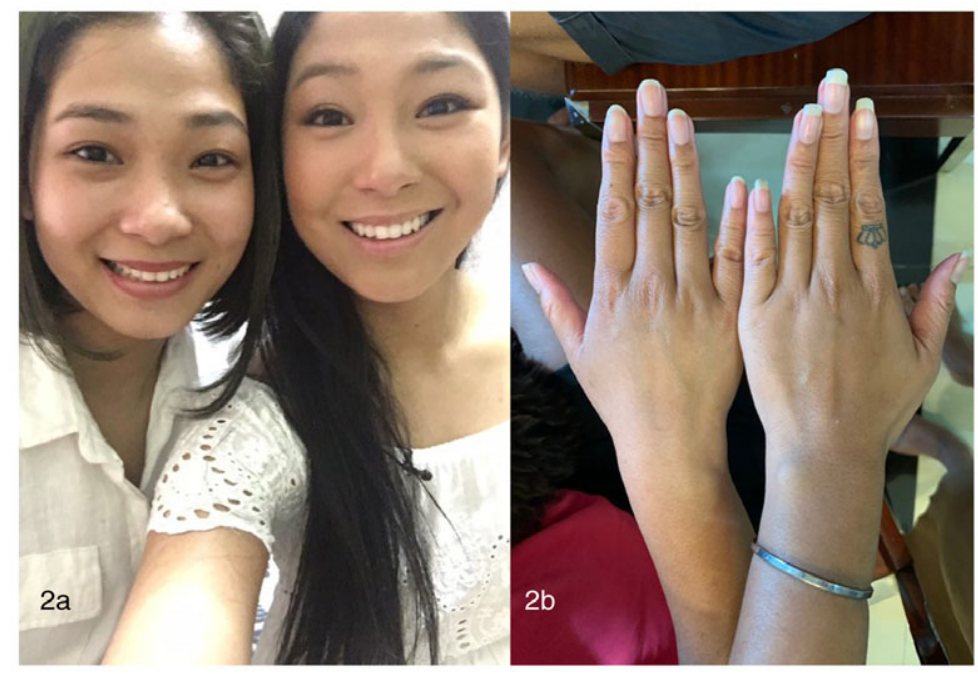

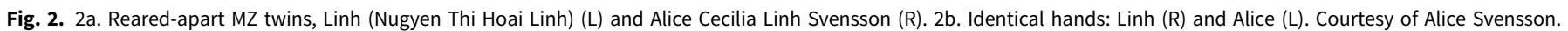

had been adopted. She describes herself as a 'confident person', explaining that while she loves to travel to Vietnam, she has never felt curious about her biological family. However, Alice's physical identity to another young woman led to her surprise reunion with a twin sister she never knew she had.

Early in life, Alice began working as a television singer and host, placing second in the 'Swedish Idol' competition when she was just 16. Her success was widely circulated throughout the Vietnamese media until a journalist contacted her to say that he had found her mother and sister. 'It was a shock!' Alice recalled. Following the twins' reunion several years later their story became popular in the Swedish media. According to Alice, 'We grew up in two different continents, with different cultures and with so many different conditions in life. Our body language and the way we speak and act are so similar, even though we haven't had the opportunity to grow up together'.

Unusual similarities between $\mathrm{MZ}$ reared-apart co-twins are hard to explain without reference to genetic factors. (Note: My graduate students and I are systematically studying the frequency of rare resemblances in $\mathrm{MZ}$ reared-apart [MZA] and dizygotic reared-apart [DZA] twin pairs. We anticipate more frequent and atypical MZA similarities, consistent with genetic effects.) As an example, when Alice was a child, her doctor informed her parents that she had a hoarse voice because she screamed so often. However, having met Linh she now suspects that her voice quality is linked to their shared genetic background. 'We are naturally hoarse', she said. Interestingly, Alice is a professional singer and artist, whereas her sister cannot sing. She attributes this difference to her sister's lack of opportunity, reflected in their different educational backgrounds. Alice attended preschool and high school before completing courses in leadership and business development, focusing on personal growth. Linh attended preschool only, receiving no higher education. She works in a nail salon and is married with two daughters. Alice is still single.

Alice finds it remarkable that the twins' hair texture, body type and hand shape are so alike despite their contrasting diets. Of course, some physical traits are less affected by environmental influences than others. The twins' nearly identical faces and hands (except for a tattoo on Linh's forefinger) are shown in Figures $2 \mathrm{a}$ and $2 \mathrm{~b}$. Both twins are right-handed.
No one is certain of the events leading to Alice and Linh's separation, estimated to have occurred when they were six to eight months of age. Alice believes this uncertainty is linked to the proud Vietnamese culture whose members are reluctant to acknowledge inabilities surrounding family planning and child rearing. Both newborns were quite sick, making it difficult for their unmarried mother to care for them. She brought Alice to the twins' birth hospital in an area of Hanoi known as Ha-tay where the infant was adopted by a Swedish couple of her mother's choosing. Their mother tried to raise Linh, but this task proved too difficult, so Linh began living with her grandparents. When Linh was 14 years old, she moved into her mother's home, but never felt quite comfortable in that environment - by then, her mother was part of a new family with three children of her own. Several years later, at age 18 years, Linh returned to live with the grandparents who raised her, eventually moving in with her husband and his family.

There are interpair differences in the social connection and emotional expressivity surrounding twin reunions. I suspect that these variations largely reflect the personalities of the twins involved, although cultural norms and language barriers may affect bonding. I witnessed several twin reunions during my association with the Minnesota Study of Twins Reared Apart and subsequently (via direct observation, documentary films and televised footage). I also learned about the nature of some first meetings from the twins' descriptions. Most twins (like Mirta and Dolores) were quite demonstrative and emotionally affected when they first met, but other twins had a more subdued experience. Alice and Linh fell into the second category. According to Alice, 'It was not that touching as many people might have thought that it would be. A lot of people said to me that "you will feel an instant feeling of love and a strong connection of belonging to each other."' In fact, Alice and Linh felt a mix of emotions. 'I think both of us felt that we were different from each other even though we looked the same.'

Alice's last comment partly reinforces my finding from a study of social relationships between unrelated look-alikes (Segal, Arch et al., 2020). I found that very few of these pairs expressed the same level of closeness and familiarity as MZ or DZ twins, despite their identical appearance. I concluded that unrelated look-alikes do not perceive the behavioral similarities that I believe bind twins together. Of course, MZA twins are as similar in personality as 
MZ twins reared together (Tellegen et al., 1988), so how was it that Alice and Linh did not feel an immediate bond despite sharing identical genes? It is likely that the cultural differences between them, Alice's disinterest in her biological family and/or the twins' language barrier affected the expression of their genetically based predispositions, dampening the rapport they might have otherwise experienced. However, what matters now is that these twins stay in touch, are getting acquainted and hope to meet in the near future. This level of effort is strong testimony to the significance of having and finding a twin.

I may consider gathering data from these two pairs. The fact that they have known each other for a long time is not necessarily an excuse for excluding them from research. A reared-apart twin sample composed of twins with varying degrees of contact allows a look at the question of whether or not contact frequency is associated with similarity. The Minnesota Study of Twins Reared Apart found that it was not (Segal, 2012), but additional data may persuade hard critics - especially if the twins were raised in different countries and cultures.

\section{Twin Research}

\section{Memorial Tribute to Isaac Blickstein, MD}

Our esteemed twin research colleague, Dr Isaac Blickstein, passed away on April 22, 2020, following a long illness (Grüenbaum \& Chervenak, 2020). He is survived by his wife and two daughters. I knew Dr Blickstein for many years through our membership in the International Society for Twin Studies and attendance at their triennial — now biennial — congresses. However, I was able to know him better at the 2012 congress held in Florence when we and several other attendees viewed an exhibit of Dr David Teplica's original twin photograph collection. The display, titled "'Gemelli: Arte e Scienza", 25-year Retrospective Exhibition of Twin Imagery', was held at the Istituto degli Innocenti. Isaac was great company and enthusiastic about everything twin related.

Dr Isaac Blickstein has an impressive academic history. $\mathrm{He}$ was a graduate of Tel Aviv University's School of Medicine before becoming Professor at the Hadassah-Hebrew University School of Medicine, in Jerusalem. He was also a faculty member in the Department of Obstetrics and Gynecology at the Kaplan Medical Center, in Rehovot. He is famous for his many twin research articles and books.

One of Isaac's papers stands out for me. During the writing of my book Twin Mythconceptions (Segal, 2017), I came across his article on the conjoined twins of Löwen (Blickstein, 2000). This work was a great addition to my chapter on conjoined twinning by addressing the controversy over the cause of this rare biological event (zygotic fission or fusion) in a novel way. He described an etching on a handbill, dated 1547, depicting opposite-sex syncephalus conjoined twins (twin with a single head and two bodies). Isaac noted that, at that time, drawings were often made by artists who witnessed real medical cases. However, he noted that some details of this depiction were inaccurate (e.g., the separate umbilical cords; the incorrect orientation of the arms), suggesting that the artist never saw the case. Alternatively, he suggested that the artist captured opposite-sex conjoined twins with a true case of syncephalus, but with some features inaccurately displayed. Still, Isaac admitted that we have a great deal to learn about the processes that give rise to variant twin forms. That paper and my communication with another expert suggests that while most scientists believe fission is responsible for conjoined twinning, fusion cannot be excluded. I also learned that one of Isaac's hobbies was art and medicine, no doubt explaining his interest in this etching.

It is impossible to list all of Isaac Blickstein's publications, but I must mention two of his 12 authored or edited books. The first is Multiple Pregnancy: Epidemiology, Gestation and Perinatal Outcome, coedited with our late colleague and MZ twin, Louis G. Keith (Blickstein \& Keith, 2005). That wonderful volume which I consult often - won the 2005 British Medical Association's award for best medical book in obstetrics and gynecology. The other book I must mention is Isaac's last one, published in 2020 and titled, Why Are Monozygotic Twins Different: From Genetics to Environment (Matias \& Blickstein, 2020). I mention it because I have a chapter in that book (Segal, Nedelec et al., 2020), and because I was initially reluctant to write it due to other obligations. However, writing a chapter for a book edited by two highly thought of twin researchers - Drs Alexandra Matias and Issac Blickstein - convinced me to contribute.

\section{Infanticide and Sacrifice of Archaic-Aged Twins and Triplets}

We rarely consider infanticide and sacrifice of babies in western nations, but such practices have occurred. A database of 480 archaic-aged babies, born between 7000 and 3500 years ago, were buried in the Ohio Valley and examined by Claassen (2013). (The Archaic period refers to hunter-gatherer societies in the American continents that existed from approximately 8000 to 2000 years BC; see Hirst, 2018.) The remains were organized into fetuses, newborns and infants between 2 and 24 months of age. It is likely that among the remains were seven sets of twins and one set of triplets; a second triplet set was detected in utero. The multiple birth status of the babies was suggested by the fact that two individuals were buried together. For example, seven newborns were buried with other newborns only, comprising the probable seven pairs of twins.

Among the 480 babies, 55 were classified as ritual killings and 16 as infanticide. These numbers were based on burial position, inclusion in group burials, uniqueness of a site and other factors. It is unclear whether the twins and/or triplets were among them. This would not be surprising, given that one or more multiple birth babies have been sacrificed in societies that regarded the birth of twins as harbingers of bad luck (Segal, 2017).

\section{Prehistoric Twin Burials}

In research related to the paper summarized above, it was noted that evidence for prehistoric twin burials is rare (Flohr, 2014). The explanation for this is that observing two buried individuals does not necessarily trigger the idea of twinship. However, twins may be suspected when individuals are buried close together in unusual positions, appear to be the same age and have skeletal and/or dental characteristics in common. A possible twin pair was discovered in 2001, at an Iron Age (1200 BC to $100 \mathrm{BC}$ ) settlement at a site near Ochtendung (Emminger Höfe), state of Rhineland-Palatinate, Germany. Supporting evidence consisted of the two individuals' nearly identical deposition in the same house pit and matching developmental status of bones and teeth. For example, the lower left first molar showed a similar configuration of its disto-buccal cusps on the surface of the tooth in both remains. It was also noted that the nature of burials of suspected twins vary at other sites, possibly reflecting different cultural attitudes toward twins. 


\section{Highlights from a Conference on the Documentary Film Three Identical Strangers}

A virtual conference, 'Multiple Perspectives on Multiples', took place on May 14-15, 2021. The conference was sponsored by the Los Angeles Institute and Society for Psychoanalytic Studies (LAISPS) and organized by Dr Linda Sobelman (2021), clinical psychologist and psychoanalyst in Los Angeles. The evening of May14 included a viewing of the recent documentary film, Three Identical Strangers (Wardle, 2018). This film focused on a set of MZ male triplets who were part of a New York City study that covertly tracked the development of separated twins and triplets during the 1960s and 1970s (see Segal, in press). Following the viewing was a presentation by Dr. Nancy L. Segal that included a film discussion, New York City twin study commentary and summary of findings from the Minnesota Study of Twins Reared Apart. The next day there were presentations from psychoanalysts Dr Ricardo Ainslie (University of Texas, Austin) and Vivienne Lewin (clinical private practice in Great Britain, now retired) and a panel discussion that included Dr Segal. The two psychoanalysts brought viewpoints to the topic that differed from Dr Segal's behavioral-genetic perspective, but everyone agreed that twinship is a significant relationship in the lives of twins and their families. A volume including the conference presentations and discussions, and twin-based contributions from other psychoanalytically oriented psychologists, is planned.

As part of her presentation, Dr Vivienne Lewin displayed an intriguing ibeji (statuette celebrating twins born to the Yorùbá people of Nigeria). Created by Yinka Shonibare in 2015, it is titled '(Twins) Riding a Butterfly'. We see two individuals dressed very differently, straddling a big butterfly and holding the reins as they travel; the ibeji can be viewed at https://i.pinimg.com/ originals/e7/37/97/e73797d9f8630a039b84b2fd417a1146.jpg. The twins appear to be female and are most likely nonidentical due to the high DZ twinning rate for which the Yorùbá people are known (Segal, 2014).

\section{Media Reports}

\section{An Atypical Twin Father}

An extraordinary case of disputed paternity occurred in Washington State in 2014, but was reported in the press this year (Hale, 2021). Following treatment for infertility by the couple, it was determined that father and child shared $25 \%$ of their genes, much less than the $50 \%$ shared by biological parents and children. Laboratory error and infidelity were ruled out - then it was discovered that the father was a chimera. A chimera is an organism composed of DNA that originated from two cell lines. In this case, the disputed father's unborn twin was lost early in his mother's pregnancy, and the paternal cells of the newborn came from the twin. Specifically, it was a case of tetragametic chimerism (involving four gametes) in which two eggs are fertilized by two sperm, after which the zygotes merge at the blastocyst stage, yielding a single individual with different cells lines throughout the body. The rare aspect in this case was that the twins' cells were incorporated into the man's reproductive cells. This case has been published in the medical literature; see Sheets et al. (2018).

\section{An Actor's Twin Brother}

Actor Ashton Kutcher has a twin brother Michael who is affected with cerebral palsy (CP). The twins appear to be fraternal, based on inspection of photographs (Russian, 2021). In 2003, Ashton spoke publicly about his brother's condition, angering him because Michael did not wish to become 'the face of CP'. However, in a 2021 interview, Michael admitted that he is grateful to Ashton for allowing him to be himself and for supporting him throughout their childhood (Edmonds, 2021). Michael is married, the father of three children and a spokesperson for the Cerebral Palsy Foundation.

\section{A Twin Link to the Tulsa, Oklahoma Massacre}

The 100th anniversary of the two-day Tulsa, Oklahoma massacre was May 31-June 1,2021. The black residents of a prosperous residential area of Tulsa, known as Greenwood, were brutally harmed and their businesses destroyed by a white supremacist mob. Given the many people whose lives were lost and disrupted, I wondered if there were twins among them. I did not find any, although there might well be. However, I did locate a story by Tiffany Crutcher, a surviving twin whose unarmed twin brother Terrence was killed by Tulsa police in 2016 (Crutcher, 2020). Terrence was 40 years old at the time (Eversley, 2016) - he had aroused suspicion on the part of police because he looked like a 'bad dude'. In fact, Terrence was a student at Tulsa Community College.

Crutcher's essay references her great-grandmother, Rebecca Brown Crutcher, who lived in Tulsa at the time of the massacre. She was one of 10,000 residents forced to abandon their homes. Like many of Greenwood's inhabitants she never spoke of this event, and it was never taught in public schools in Tulsa or anywhere else in the USA. However, the anniversary has drawn attention to what happened there 100 years ago. Many members of the younger generations are learning about their family histories for the first time. They are also learning that reparations have never been made. The killing of Tiffany's twin brother reminds her of a difficult past and an uneasy future.

\section{The Birth of Superfetated Twins}

Superfetated twins are fraternal twins in which the two eggs are fertilized three to four weeks apart. Such twins can, however, be born on the same day. Once fertilization takes place, it is unusual for another egg to be released in what would presumably be the subsequent menstrual cycle. Superfetation is considered a rare twinning event, but its frequency is difficult to determine, especially since some cases may go undetected. A review of the literature revealed only 10 documented pairs (Pape et al., 2008). However, case reports of superfetation have appeared subsequently; see Lantieri et al. (2010).

In fact, another case of superfetated twins was reported only recently (Page, 2021). Rebecca Roberts of Wiltshire, England, became pregnant for the first time at age 39 . When she returned to the hospital for a second ultrasound five weeks later (her 12th gestational week), she learned that she was carrying a second fetus that was much less developed than the first one. Superfetation was confirmed by tracking the progress of the second twin, showing that development was consistently delayed by three weeks. The babies were delivered two minutes apart by cesarean section at 33 weeks' gestation, due to umbilical cord problems affecting the second twin. A male (Noah) was born first, weighing four pounds, ten ounces, followed by a female (Rosalie) weighing two pounds, seven ounces. After a prolonged hospital stay Rosalie is doing well. 


\section{Twin Comedians and Script Writers}

Kenny and Keith Lucas are known as 'the Lucas Brothers' (Riley, 2021). These identical twins have become famous as comedians, but a recent change in their career paths has earned them greater acclaim. The Lucas twins wrote the screenplay for Judas and the Black Messiah, an Oscar-nominated film for best original screenplay. While developing a script with co-writer/director Shaka King, the twins were put in touch with Will Berson, who was working on a similar project. This professional connection and the film's nomination launched the twins into stardom, even though the film did not win the award.

The twins' parallel career paths are fascinating to follow. Both had been enrolled in law school prior to entering the entertainment world. Kenny had attended New York University's law school, but left in this third year to test his comedic skills. Keith, a student at Duke University's law school, was somewhat more committed than his brother to becoming an attorney, but claims that when he was on stage, he felt the passion that he never experienced from his legal studies. Twin studies show that intrinsic job satisfaction is partly genetically influenced (Arvey et al., 1989); thus, the Lucas twins' career paths and final choices are to be expected.

\section{Indian Twins' Tragic Loss to COVID-19}

Newspapers have featured a number of cases in which identical twins have either both succumbed to COVID-19 infection or were both infected but to varying degrees of severity. Some twin researchers are conducting studies to assess genetic and environmental influences surrounding the virus (Segal, 2020). Hopefully, some answers will be available soon.

A recent case of identical twins who lost their lives from COVID-19 comes from India (Gettleman \& Raj, 2021). Twentyfour-year-old male twins, Joefred (Joefil) and Ralfred (Ralfi) Gregory, were inseparable. They enrolled in the same college, both majoring in computer science. Their identical appearance was accented by their matching outfits and beards. Their relationship with one another was one of tremendous love - people who knew them observed that they were rarely seen apart. Unfortunately, both twins were infected with COVID-19 in April 2020 and when they entered the hospital a week later their disease had progressed considerably. Both twins were placed on ventilators in the intensive care unit. Joefred passed away on May 13, one day before his twin brother, Ralfred. The twins' mother knew this but kept the truth from her twin son who was still alive. Ralfred felt that his mother was not being honest, believing instead that his brother was gone, and he suffered a severe depression. (The twins' beds were close by and Joefred was not there. Ralfred passed away the following day.)

Acknowledgements. I wish to acknowledge the cooperation of the twins who appear in this article, the generous assistance of Dr. Laura A. Pergola, founder of Multifamilias (Multi-families) in Argentina and the skillful arrangement of photographs by Kelly Donovan, graphic artist (and identical twin) at California State University, Fullerton.

\section{Conflict of interest. None.}

Ethical standards. This paper was written in conformance with ethical standards sets forth by my institution.

\section{References}

Arvey, R. D., Bouchard, T. J., Jr., Segal, N. L. \& Abraham, L. M. (1989). Job satisfaction: environmental and genetic components. Journal of Applied Psychology, 74, 187-192.

Blickstein, I. (2000). The conjoined twins of Löwen. Twin Research, 3, 185-188.

Blickstein, I., \& Keith, L. G. (2005). Multiple pregnancy: Epidemiology, gestation and perinatal outcome. CRC Press.

Claassen, C. (2013). Infanticide and sacrifices among Archaic babies of the central United States. World Archaeology, 45, 298-313.

Crutcher, T. (2020, June 19). We're still not free. Time Magazine. https://time. com/5856248/tiffany-crutcher-juneteenth-trump-rally/

DuoLingo. (2021, March 11). Episode 80: Strangely identical. https://podcast. duolingo.com/episode-80-extranamente-identicas-strangely-identical

Edmonds, L. (2021, May 22). Ashton Kutcher's twin brother was 'very angry' when actor revealed he had cerebral palsy. Yahoo!News. https://news.yahoo. com/ashton-kutchers-twin-brother-very-153447086.html

Eversley, M. (2016, September 19). Video shows unarmed black man Terence Crutcher shot by Tulsa Officer. USA Today. https:/www.usatoday.com/ story/news/2016/09/19/police-involved-shooting-black-man-tulsa-promptsinvestigation/90716058/

Flohr, S. (2014). Twin burials in prehistory: A possible case from the Iron Age of Germany. International Journal of Osteoarchaeology, 24, 116-122.

Gettleman, J., \& Raj, S. (2021, May 19). These twins lived together. In Covid, they died together. New York Times. https://www.nytimes.com/2021/05/19/ world/asia/virus-india-twins-deaths.html

Grüenbaum, A., \& Chervenak, F. A. (2020, May 20). Issac Blickstein, M.D. (1953-2020). De Gruyter. https://www.degruyter.com/document/doi/10. 1515/jpm-2020-0196/html

Hale, T. (2021, April 1). A man's unborn twin fathered his son thanks to genetic chimerism. IFLScience. https://www.iflscience.com/health-and-medicine/amans-unborn-twin-fathered-his-son-thanks-to-genetic-chimerism/

Hirst, K. K. (2018, May 25). Archaic period 3/4 Ancient American huntergatherers. ThoughtCo. https://www.thoughtco.com/archaic-period-americanhunter-gatherers-169976

Lantieri, T., Revelli, A., Gaglioti, P., Menato, G., Gennarelli, G., Delle Piane, L., \& Massobrio, M. (2010). Superfetation after ovulation induction and intrauterine insemination performed during an unknown ectopic pregnancy. Reproductive Biomedicine Online, 20, 664-666.

Matias, A., \& Blickstein, I. (Eds.). (2020). Why are monozygotic twins different: From genetics to environment. Elsevier.

Page, S. (2021, April 8). Woman gets pregnant while already pregnant, gives birth to twins conceived 3 weeks apart. Washington Post. https://www. washingtonpost.com/lifestyle/2021/04/08/conceive-baby-while-pregnant/

Pape, O., Winer, N., Paumier, A., Philippe, H. J., Flatrès, B., \& Boog, G. (2008). Superfetation: about a case and review of the literature. Journal of Obstetrics, Gynecology and Reproductive Biology, 37, 791-795.

Riley, J. (2021, March 26). The Lucas Brothers on LaKeith Stanfield's surprise nomination and scripting 'Judas and the Black Messiah'. Variety, https://variety.com/2021/film/awards/the-lucas-brothers-judas-and-the-blackmessiah-podcast-1234938434/

Russian, A. (2021, May 21). Ashton Kutcher's twin brother Michael was 'Very angry' when Ashton revealed he has cerebral palsy. People Magazine. https:// people.com/movies/ashton-kutchers-twin-brother-michael-was-very-angrywhen-ashton-revealed-he-has-cerebral-palsy/

Segal, N. L. (2012). Born together, reared apart: The landmark Minnesota Twin Study. Harvard University Press.

Segal, N. L. (2014). Art for twins: Yorùbá artists and their statues. Twin Research and Human Genetics, 17, 215-221.

Segal, N. L. (2017). Twin mythconceptions. Elsevier.

Segal, N. L. (2020). COVID-19: twin research in progress. Twin Research and Human Genetics, 23, 259-263.

Segal, N. L. (in press). Deliberately divided: Inside the controversial study of twins and triplets adopted apart. Rowman \& Littlefield.

Segal, N. L., Arch, D. A. N., Preston, K. S. J., \& Marelich, W. D. (2020). Social closeness revisited in monozygotic and dizygotic twin families: Aunt/uncle-niece/nephew relations. Personality and Individual Differences, 157C, 109815. 
Segal, N. L., Nedelec, J. L.f, \& Costello-Harris, V. (2020). Differences in development in monozygotic twins. In A. Matias \& I. Blickstein (Eds.), Why are monozygotic twins different: From genetics to environment (pp. 285-295). Elsevier.

Sheets, K. M., Baird, M. L., Heinig, J., Davis, D., Sabatini, M., \& Starr, D. B. (2018). A case of chimerism-induced paternity confusion: What ART practitioners can do to prevent future calamity for families. Journal of Assisted Reproduction and Genetics, 35, 345-352.
Sobelman, L. (2021, May). Twins: Multiple Perspectives on Multiples (Virtual Conference), Los Angeles Institute and Society for Psychoanalytic Studies. Tellegen, A., Lykken, D. T., Bouchard, T. J., Jr., Wilcox, K. J., Segal, N. L. \& Rich, S. (1988). Personality similarity in twins reared apart and together. Journal of Personality and Social Psychology, 54, 1031-1039.

Wardle, T. (2018). Three identical strangers. Raw Films. 